\title{
Volume of Derivative Trading, Enterprise Value, and the Return on Assets
}

\author{
Jin-Yong Yang \\ Department of International Business, Hankuk University of Foreign Studies, Seoul, Korea \\ Email: jyang0112@gmail.com
}

Received April 24, 2013; revised May 24, 2013; accepted June 24, 2013

Copyright (C) 2013 Jin-Yong Yang. This is an open access article distributed under the Creative Commons Attribution License, which permits unrestricted use, distribution, and reproduction in any medium, provided the original work is properly cited.

\begin{abstract}
We study how the volume of derivatives trading is associated with the return on assets (ROA), as well as the enterprise value proxied by abnormal return (AR), before and after the US Financial Crisis. Results suggest that before the crisis, the volume of over-the-counter trading, which tends to be less strictly regulated and thus can be more flexibly applied, is positively associated with AR and ROA, while exchange trading is not. After the financial crisis, exchange trading, which is more heavily regulated and thus has lower credit risks, is positively associated with AR and ROA. This implies that the kinds of derivatives products having a positive or negative effect on the enterprise value of financial institutions may vary according to each period of the economy. Therefore, in full consideration of the above, it is recommended that more appropriate alternatives to the regulations and inspections should be provided for derivatives products and trading methods of financial institutions.
\end{abstract}

Keywords: Derivatives Trading Volume; Enterprise Value; Return on Assets

\section{Introduction}

Derivatives trading can function positively for financial institutions. When market risks are relatively low, the volume of over-the-counter (OTC) trading of a financial institution, which tends to be less strictly regulated and thus can be more flexibly applied, is likely to have a positive association with the return on assets (ROA), as well as the enterprise value proxied by abnormal return (AR), before and after the US Financial Crisis. However, when market risks are relatively high, this association would be less clear. Instead, the volume of exchange trading, which is more heavily regulated and thus has lower credit risks, is likely to have a positive association with AR or ROA. The goal of this paper is to test these hypotheses.

The legislation of Commodity Futures Modernization Act (CFMA) in 2000 confirmed that OTC derivatives trading would not be regulated. Since then, OTC derivatives trading had actively grown until the U.S. Financial Crisis, which resulted in intensified regulation. Hence, this paper also studies the effects of derivatives trading according to economic circumstances in diverse ways.

Because most of the major financial institutions selected as samples for the study were banks and/or holding companies of the banks, ROA, which represents net profit during the term based on assets size can be ex- plained as the profit performance index of the banks. The AR is the realized return net of the expected return. This approach is also adopted in Ryu, Baek, Yang and Chae [1], closely related to this paper.

Ryu, Baek, Yang and Chae [1] document a positive association between derivatives trading volume, both OTC and exchange, and AR and ROA for major U.S. financial institutions. In addition, they analyze a similar association by the type of financial institution on the business performance. This paper studies how the association differs according to the market risks, in order to understand the mechanism of derivatives trading. This is meaningful especially because different regulations and supervisions have been applied for OTC and exchange derivatives. In addition, the derivatives market situation before and after the financial crisis has changed quite a bit and accordingly, it is expected that the effect on the business performance of the financial institutions that traded the derivatives would be different depending on the market situation.

Numerous papers study the derivatives market. Ryu, Baek, Yang and Chae [1] document that an increase in exchange of OTC option trading volumes is positively associated with AR. However, an increase in futures and credit derivatives is negatively associated with AR. In 
addition, Kwon, Park and Chang [2] report that derivatives trading volumes are positively associated with AR. This suggests that derivative trading would improve the AR.

Jalivand [3] documents that the integrated level of company size, efficiency of business, and financial activities of a company are the major determinants of derivatives traders, for non-financial institutions in Canada. In a study of the listed companies in Nordic economies, Brunzell, Hansson, and Liljeblom [4] find that most firms trade derivatives for the purpose of hedging, but more than a majority of firms were seeking returns in addition to hedging. Ahmed, Kilic, and Lobo [5] study the effects of SFAS 133, the financial accounting standard for derivatives, on the risk relevance of accounting measures of derivative exposures.

This paper is organized as follows. Section 2 discusses the research method. Section 3 provides the results. Section 4 concludes.

\section{Models and Data}

\subsection{Empirical Models}

Our main hypothesis is that an increase in derivatives trading volume of a major financial institution is positively associated with ROA and AR. Our regression models are similar to the one used at Kwon, Park, and Chang [2]. To be specific, for ROA, we consider

$$
\begin{aligned}
\mathrm{ROA}_{\mathrm{it}} & =\alpha_{1}+\beta_{1} \mathrm{DEX}_{\mathrm{it}}+\beta_{2} \mathrm{DOTC}_{\mathrm{it}}+\beta_{3} \mathrm{CBI}_{\mathrm{it}} \\
& +\beta_{4} \mathrm{CPO}_{\mathrm{it}}+\beta_{5} \mathrm{CTO}_{\mathrm{it}}+\beta_{6} \mathrm{CCA}_{\mathrm{it}} \\
& +\beta_{7} \mathrm{SIZE}_{\mathrm{it}}+\beta_{8} \mathrm{LEV}_{\mathrm{it}}+\beta_{9} \mathrm{INF}_{\mathrm{t}} \\
& +\beta_{10} \mathrm{GDP}_{\mathrm{t}}+\beta_{11} \mathrm{UN}_{\mathrm{t}}+\varepsilon_{\mathrm{it}},
\end{aligned}
$$

where $\mathrm{ROA}_{i t}$ is the net profit divided by total assets of institution $\mathrm{i}$ at period t. Here, $\mathrm{DEX}_{\mathrm{it}}$ and $\mathrm{DOTC}_{\mathrm{it}}$ are trading volumes of exchange derivatives and OTC derivatives, respectively, measured by gross notional amount of derivatives divided by total assets. Control variables follow. $\mathrm{CBI}_{\mathrm{it}}$ is bilaterally netted credit equivalent exposures, $\mathrm{CPO}_{i t}$ is the credit equivalent exposures measuring potential future exposure to market prices volatility, $\mathrm{CTO}_{\text {it }}$ is the risk exposure to assets on total credit exposure, and $\mathrm{CCA}_{\text {it }}$ is the total credit exposure to total assets. Each of $\mathrm{CBI}_{i t}, \mathrm{CPO}_{i t}, \mathrm{CTO}_{i t}$ and $\mathrm{CCA}_{i t}$ is normalized by total assets. In addition, SIZE $_{\text {it }}$ is the asset size and $\mathrm{LEV}_{\text {it }}$ is the debt level, while $\mathrm{INF}_{\mathrm{t}}, \mathrm{GDP}_{\mathrm{t}}$ and $\mathrm{UN}_{\mathrm{t}}$ are inflation rate, the growth rate of GDP per capita, and unemployment rate, respectively.

In addition, for $\mathrm{AR}$, we consider

$$
\begin{aligned}
\mathrm{AR}_{\mathrm{it}}= & \mathrm{a}_{1}+\mathrm{b}_{1} \mathrm{DEX}_{\mathrm{it}}+\mathrm{b}_{2} \mathrm{DOTC}_{\mathrm{it}}+\mathrm{b}_{3} \mathrm{SIZE}_{\mathrm{it}} \\
& +\mathrm{b}_{4} \mathrm{LEV}_{\mathrm{it}}+\mathrm{b}_{4} \mathrm{INF}_{\mathrm{t}}+\mathrm{b}_{6} \mathrm{GDP}_{\mathrm{t}}+\mathrm{b}_{7} \mathrm{UN}_{\mathrm{t}}+\mathrm{e}_{\mathrm{it}},
\end{aligned}
$$

where $\mathrm{AR}_{\mathrm{it}}$ is the average abnormal return of institution $\mathrm{i}$ at period t. To obtain AR, we first obtain daily observa- tions on the market yield based on the S\&P 500 index. We then obtain ROAs from daily closing prices of each financial institution. Using the period from -220 days to -21 days from the end of the 4th quarter 2001 (i.e., September 30, 2001), we regress ROA of each financial institution on market yield to obtain beta. The AR of each financial institution is obtained as the residual at each period. The average of such ARs in each quarter was calculated for analysis by quarter.

The results of previous studies document positive associations between risk management and enterprise value according to derivatives trading. Hence, we expect that the signs for $\beta_{1}, \beta_{2}, \mathrm{~b}_{1}$ and $\mathrm{b}_{2}$ are positive. In addition, $\beta_{7}$, $\beta_{8}, b_{3}$ and $b_{4}$ are also expected to be positive since it has been documented that size and leverage are positively associated with ROA. We use the size of a firm $\left(\mathrm{SIZE}_{\mathrm{it}}\right)$ and its debt level $\left(\mathrm{LEV}_{\mathrm{it}}\right)$ as control variables. They were used in previous research on risk management and performance. In particular, Jalivand [3] argue that the size is one of important factors to induce the use of derivatives. That is, large-sized firms will engage in more derivatives trade. Hence, the slope for $\mathrm{SIZE}_{\mathrm{it}}$ is expected to be positive.

It is also expected that $\mathrm{INF}_{\mathrm{t}}$ and $\mathrm{GDP}_{\mathrm{t}}$ would have a positive correlation with $\mathrm{ROA}_{\mathrm{it}}$ and $\mathrm{AR}_{\mathrm{it}}$ since a positive shock in monetary policy or GDP growth would positively affect the asset returns. Similarly, $\mathrm{UN}_{\mathrm{t}}$ would be negatively correlated with $\mathrm{ROA}_{\mathrm{it}}$ and $\mathrm{AR}_{\mathrm{it}}$. (For related discussions on how macroeconomic variables are related with $\mathrm{ROA}_{\text {it }}$ and $\mathrm{AR}_{\mathrm{it}}$, see, for example, Fu and Heffernan [6]) As this study used exchange/OTC derivatives trading volume by quarters for 40 quarters, the circumstances according to time and economic situation in each quarter should be taken into account. For this purpose, this study employed variables of inflation, GDP, and unemployment rate, which were used as the macroeconomic variables in the study of $\mathrm{Fu}$ and Heffernan [6].

\subsection{Data}

Time is quarterly. The observations on the unemployment rate and the real GDP growth rate are the averages of three monthly observations. The periods are classified into before (2001Q4-2007Q2) and after (2007Q32011Q3) the break of US Financial Crisis.

We consider major financial institutions, including commercial banks, trust companies, bank holding companies and financial holding companies, in the United States. They are major traders in the US derivatives market. To be specific, they consists of banks and trust companies (Bank of America, Bank of New York Mellon, Citibank, JPMorgan Chase Bank, Keybank, PNC Bank, State Street Bank \& Trust Co., Suntrust Bank, U.S. Bank, and Wells Fargo Bank) and banks and financial holding companies (Bank of America Corporation, Bank of New 
York Mellon Corporation, Citigroup Inc. HSBC North America Holdings Inc., JPMorgan Chase \& Co., Keycorp, Northern Trust Corporation, PNC Financial Services Group, Inc., State Street Corporation, Suntrust Banks, Inc., U.S. Bancorp, and Wells Fargo \& Company).

The data are obtained from the Office of the Comptroller of the Currency (OCC) and investor relations (FDIC insured commercial bank, OCC, call report).

Table 1 provides the descriptive statistics, for banks and trust companies and for banks and financial holding companies, respectively. Table 2 provides correlation coefficients. The coefficients are positive and high among risk measures, i.e., $\mathrm{CBI}_{\mathrm{it}}, \mathrm{CPO}_{\mathrm{it}}, \mathrm{CTO}_{\mathrm{it}}$ and $\mathrm{CCA}_{\mathrm{it}}$.

\section{Results}

\subsection{Regression Results}

Table 3 summarizes the regression results. Part (A) estimates Model (1) for banks and trust companies. For
"Before the Crisis" sample of 2001Q4-2007Q2, the variables, $\mathrm{CBI}_{\mathrm{it}}, \mathrm{CPO}_{\mathrm{it}}, \mathrm{CTO}_{\mathrm{it}}$, and constant term have correlations with independent variables. In order to eliminate multicollinearity, they were removed from the analysis. In Estimations of (1) and (2), we obtain the variance inflating factor $(\mathrm{VIF})$ as $\mathrm{VIF}_{\mathrm{j}}=1 /\left(1-\mathrm{R}_{\mathrm{j}}^{2}\right)$, where $R_{j}^{2}$ is the $R$ squared when $X_{j}$ is regressed on all other explanatory variables. The variables with VIFs exceeding 10 are excluded for a concern of multicollinearity. Those variables are reported in Table 4.

The results suggest that exchange-traded derivatives trading volume has a significant negative (-) correlation at the level of $1 \%$. On the other hand, OTC derivatives trading volume has a significant positive $(+)$ correlation at the level of $5 \%$. This implies that banks and trust companies can improve their returns by increasing OTC derivatives trading volume. On the other hand, the analysis of the relation between derivatives trading volume and ROA of banks and investment companies after the

Table 1. Descriptive statistics. (a) Banks and trust companies; (b) Banks and financial holding companies.

(a)

\begin{tabular}{|c|c|c|c|c|c|c|}
\hline Variable & \#Obs & Mean & Standard Deviation & Min & Median & Max \\
\hline $\mathrm{ROA}_{\mathrm{it}}$ & 400 & $0.57 \%$ & $0.56 \%$ & $-1.80 \%$ & $0.53 \%$ & $2.98 \%$ \\
\hline $\mathrm{DEX}_{\mathrm{it}}$ & 400 & 0.89 & 1.21 & 0.00 & 0.42 & 7.62 \\
\hline DOTC $_{\text {it }}$ & 400 & 11.41 & 0.79 & 15.80 & 0.15 & 70.23 \\
\hline $\mathrm{CBI}_{\mathrm{it}}$ & 400 & 0.05 & 0.10 & 0.00 & 0.03 & 1.03 \\
\hline $\mathrm{CPO}_{\mathrm{it}}$ & 400 & 0.10 & 0.26 & 0.00 & 0.02 & 2.50 \\
\hline $\mathrm{CTO}_{\text {it }}$ & 400 & 0.14 & 0.35 & 0.00 & 0.05 & 3.53 \\
\hline $\mathrm{CCA}_{\mathrm{it}}$ & 400 & 0.00 & 0.02 & 0.00 & 0.00 & 0.31 \\
\hline SIZE $_{\text {it }}$ & 400 & 25.90 & 0.89 & 24.23 & 25.67 & 27.33 \\
\hline $\mathrm{LEV}_{\mathrm{it}}$ & 400 & 0.01 & 0.11 & 0.00 & 0.00 & 0.90 \\
\hline $\mathrm{INF}_{\mathrm{t}}$ & 400 & 2.02 & 0.53 & 1.23 & 1.90 & 2.90 \\
\hline $\mathrm{GDP}_{\mathrm{t}}$ & 400 & 0.02 & 0.01 & 0.00 & 0.02 & 0.04 \\
\hline $\mathrm{UN}_{\mathrm{t}}$ & 400 & 0.06 & 0.00 & 0.05 & 0.06 & 0.06 \\
\hline
\end{tabular}

(b)

\begin{tabular}{|c|c|c|c|c|c|c|}
\hline Variable & \#Obs & Mean & Standard Deviation & Min & Median & Max \\
\hline $\mathrm{AR}_{\text {it }}$ & 480 & -0.02 & 0.03 & -0.09 & 0.00 & 0.00 \\
\hline $\mathrm{DEX}_{\mathrm{it}}$ & 480 & 8.54 & 12.26 & 0.17 & 2.88 & 62.39 \\
\hline DOTC $_{\text {it }}$ & 480 & 0.37 & 0.47 & 0.00 & 0.21 & 3.18 \\
\hline SIZE $_{\text {it }}$ & 480 & 26.41 & 1.12 & 24.32 & 26.22 & 28.50 \\
\hline
\end{tabular}

Note: $\mathrm{ROA}_{\mathrm{it}}$ is the net profit divided by total assets of institution $\mathrm{i}$ at period $\mathrm{t}$. $\mathrm{DEX}_{\mathrm{it}}$ and DOTC $\mathrm{it}_{\mathrm{it}}$ are trading volumes of exchange derivatives and OTC derivatives, respectively, measured by gross notional amount of derivatives divided by total assets. $\mathrm{CBI}_{\mathrm{it}}$ is bilaterally netted credit equivalent exposures, $\mathrm{CPO}_{\mathrm{it}}$ is the credit equivalent exposures measuring potential future exposure to market prices volatility, $\mathrm{CTO}_{\text {it }}$ is the risk exposure to assets on total credit exposure, and $\mathrm{CCA}_{\mathrm{it}}$ is the total credit exposure to total assets. Each of $\mathrm{CBI}_{\mathrm{it}}, \mathrm{CPO}_{\mathrm{it}}, \mathrm{CTO}_{\mathrm{it}}$ and $\mathrm{CCA}_{\mathrm{it}}$ is normalized by total assets. SIZE $\mathrm{E}_{\mathrm{it}}$ is the asset size and LEV $\mathrm{V}_{\mathrm{it}}$ is the debt level, while $\mathrm{INF}_{\mathrm{t}}, \mathrm{GDP}_{\mathrm{t}}$ and $\mathrm{UN}_{\mathrm{t}}$ are inflation rate, the growth rate of GDP per capita, and unemployment rate, respectively. 
Table 2. Pearson correlation coefficients. (a) Banks and trust companies; (b) Banks and financial holding companies.

(a)

\begin{tabular}{|c|c|c|c|c|c|}
\hline & $\mathrm{DEX}_{\mathrm{it}}$ & DOTC $_{\text {it }}$ & $\mathrm{CBI}_{\mathrm{it}}$ & $\mathrm{CPO}_{\text {it }}$ & $\mathrm{CTO}_{\mathrm{it}}$ \\
\hline DOTC $_{\text {it }}$ & $0.970^{* * *}$ & & & & \\
\hline $\mathrm{CBI}_{\mathrm{it}}$ & 0.246 & 0.240 & & & \\
\hline $\mathrm{CPO}_{\text {it }}$ & $0.400^{* *}$ & $0.378^{* * *}$ & $0.972^{* * *}$ & & \\
\hline $\mathrm{CTO}_{\text {it }}$ & $0.359^{* *}$ & $0.342^{* * *}$ & $0.985^{* * *}$ & $0.998^{* * *}$ & \\
\hline $\mathrm{CCA}_{\mathrm{it}}$ & $0.917^{* * *}$ & $0.916^{* * *}$ & $0.496^{* * *}$ & $0.619^{* * *}$ & $0.588^{* * *}$ \\
\hline SIZE $_{i t}$ & $0.756^{* * *}$ & $0.721^{* * *}$ & 0.124 & 0.241 & 0.210 \\
\hline $\mathrm{LEV}_{\text {it }}$ & 0.003 & 0.001 & -0.018 & -0.014 & -0.015 \\
\hline $\mathrm{INF}_{\mathrm{t}}$ & 0.073 & 0.075 & -0.101 & -0.074 & -0.082 \\
\hline $\mathrm{GDP}_{\mathrm{t}}$ & 0.091 & 0.079 & -0.069 & -0.018 & -0.033 \\
\hline $\mathrm{UN}_{\mathrm{t}}$ & -0.012 & -0.027 & 0.049 & 0.015 & 0.024 \\
\hline
\end{tabular}

(b)

\begin{tabular}{rccc}
\hline & $\mathrm{AR}_{\text {it }}$ & $\mathrm{DEX}_{\mathrm{it}}$ & DOTC $_{\mathrm{it}}$ \\
\hline DEX $_{\mathrm{it}}$ & -0.137 & & \\
DOTC $_{\text {it }}$ & -0.127 & $0.899^{* * *}$ & $0.538^{* *}$ \\
SIZE $_{\text {it }}$ & $-0.103^{* * *}$ & $0.591^{* *}$ \\
\hline
\end{tabular}

Note: ${ }^{* * *}$ : Significant at $1 \%{ }^{* *}$ : At $5 \%{ }^{*}:$ At $10 \%$. $\mathrm{ROA}_{\mathrm{it}}$ is the net profit divided by total assets of institution $\mathrm{i}$ at period t. DEX $\mathrm{it}_{\mathrm{it}}$ and $\mathrm{DOTC}$ it are trading volumes of exchange derivatives and OTC derivatives, respectively, measured by gross notional amount of derivatives divided by total assets. $\mathrm{CBI}_{\mathrm{it}}$ is bilaterally netted credit equivalent exposures, $\mathrm{CPO}_{\mathrm{it}}$ is the credit equivalent exposures measuring potential future exposure to market prices volatility, $\mathrm{CTO}_{\mathrm{it}}$ is the risk exposure to assets on total credit exposure, and $\mathrm{CCA}_{i t}$ is the total credit exposure to total assets. Each of $\mathrm{CBI}_{i t}, \mathrm{CPO}_{\text {it }}, \mathrm{CTO}_{\text {it }}$ and $\mathrm{CCA}_{\text {it }}$ is normalized by total assets. SIZE $E_{i t}$ is the asset size and $\mathrm{LEV}_{\text {it }}$ is the debt level, while $\mathrm{INF}_{\mathrm{t}}, \mathrm{GDP}_{\mathrm{t}}$ and $\mathrm{UN}_{\mathrm{t}}$ are inflation rate, the growth rate of GDP per capita, and unemployment rate, respectively.

financial crisis showed a different pattern. The trading volume of exchange derivatives in financial institutions had a positive effect on the increase in ROA but an increase in trading volume in OTC derivatives had a negative effect on ROA.

Part (B) similarly estimates Model (2) for banks and financial holding companies. The variables, $\mathrm{CBI}_{\mathrm{it}}, \mathrm{CPO}_{\mathrm{it}}$, $\mathrm{CTO}_{\text {it }}, \mathrm{CCA}_{\text {it }}$ and $\mathrm{LEV}_{\text {it }}$ have correlations with the independent variables. They are removed from the analysis. Results suggest that before the US Financial Crisis, the trading volume of exchange derivatives has a negative effect on enterprise value. Unlike in Part (A), the trading volume in OTC derivatives has a positive effect on enterprise value. Both are significant at a $1 \%$ level. After the US Financial Crisis, an increase in trading volume of exchange derivatives had a positive effect on the AR of stocks after the financial crisis, which is different from the results before the financial crisis.

\subsection{Panel Analysis Results}

In order to test robustness of the research results, Table 5 reports additional panel data analyses. Part (A) summa- rizes the results on banks and trust companies. An increase in trading volume of OTC derivatives before the financial crisis had a negative effect on the AR of financial institutions. However, after the financial crisis, an increase in trading volume of exchange derivatives only in the panel model on random effects had a positive relationship with ROA. It is significant at a level of 5\%.

Part (B) summarizes the results on banks and financial holding companies. An increase in trading volume of OTC derivatives had a positive effect on the AR of financial institutions for the whole period of both before and after the financial crisis. As for the period after the financial crisis, an increase in trading volume of exchange derivatives only in the panel model on fixed effects had a positive relationship with enterprise value.

\section{Concluding Remarks}

Multi-regression analyses and panel analyses suggest that for major US Financial institutions, an increase in trading volume of OTC derivatives had a positive effect on ROA and $\mathrm{AR}$ of financial institutions before the financial crisis. This is because derivatives trade decreased the risk 
Table 3. Regression results of the model. (a) Banks and trust companies; (b) Banks and financial holding companies.

(a)

\begin{tabular}{ccc}
\hline Vairables & Before the Crisis $(2001 \mathrm{Q} 4-2007 \mathrm{Q} 2)$ & After the Crisis $(2007 \mathrm{Q} 3-2011 \mathrm{Q} 3)$ \\
\hline $\mathrm{DEX}$ & $-0.00^{* * *}(-2.47)$ & $-0.10(0.00)$ \\
$\mathrm{DOTC}_{\mathrm{it}}$ & $0.00^{* *}(2.27)$ & $-0.70^{*}(2.09)$ \\
$\mathrm{CBI}_{\mathrm{it}}$ & Excluded & Excluded \\
$\mathrm{CPO}_{\mathrm{it}}$ & Excluded & Excluded \\
$\mathrm{CTO}_{\mathrm{it}}$ & Excluded & Excluded \\
$\mathrm{CCA}_{\mathrm{it}}$ & $0.22(0.40)$ & Excluded \\
$\mathrm{SIZE}_{\mathrm{it}}$ & $-0.10^{* * *}(-6.41)$ & $-0.08^{* * *}(-6.84)$ \\
$\mathrm{LEV}_{\mathrm{it}}$ & $-0.04(-1.20)$ & Excluded \\
$\mathrm{INF}_{\mathrm{t}}$ & $0.00(0.33)$ & $0.00(0.46)$ \\
$\mathrm{GDP}_{\mathrm{t}}$ & $0.59(0.94)$ & $0.11(0.22)$ \\
$\mathrm{UN}_{\mathrm{t}}$ & $1.10(1.45)$ & $1.37^{* *}(2.25)$ \\
$\mathrm{R} 2 / \mathrm{Modified} 2$ & $33.4 \% / 31.6 \%$ & $32.1 \% / 30.5 \%$ \\
\hline
\end{tabular}

(b)

\begin{tabular}{ccc}
\hline Vairables & Before the Crisis $(2001 \mathrm{Q} 4-2007 \mathrm{Q} 2)$ & After the Crisis $(2007 \mathrm{Q} 3-2011 \mathrm{Q} 3)$ \\
\hline $\mathrm{DEX}_{\mathrm{it}}$ & $-0.45^{* * *}(-13.14)$ & $-0.02^{* * *}(3.92)$ \\
$\mathrm{DOTC}_{\mathrm{it}}$ & $0.18^{* * *}(5.91)$ & Excluded \\
$\mathrm{CBI}_{\mathrm{it}}$ & Excluded & Excluded \\
$\mathrm{CPO}_{\text {it }}$ & Excluded & Excluded \\
$\mathrm{CTO}_{\text {it }}$ & Excluded & Excluded \\
$\mathrm{CCA}_{\text {it }}$ & Excluded & $0.00^{* * *}(4.40)$ \\
$\mathrm{SIZE}_{\text {it }}$ & $-0.03^{* * *}(-4.06)$ & Excluded \\
$\mathrm{LEV}_{\mathrm{it}}$ & Excluded & $-0.00(-1.71)$ \\
$\mathrm{INF}_{\mathrm{t}}$ & $0.00(0.02)$ & $0.08^{* * *}(6.41)$ \\
$\mathrm{GDP}_{\mathrm{t}}$ & $0.21(0.40)$ & $-0.11^{* * *}(-6.57)$ \\
$\mathrm{UN}_{\mathrm{t}}$ & $0.86(1.38)$ & $45.2 \% / 43.9 \%$ \\
\hline
\end{tabular}

Note: Dependent Variable: $\mathrm{ROA}_{\mathrm{it}}{ }^{* * *}$ : Significant at $1 \%{ }^{* *}:$ At $5 \% .^{*}:$ At $10 \%$. $\mathrm{ROA}_{\mathrm{it}}$ is the net profit divided by total assets of institution $\mathrm{i}$ at period t. DEX $\mathrm{it}$ and DOTC $\mathrm{C}_{\mathrm{it}}$ are trading volumes of exchange derivatives and OTC derivatives, respectively, measured by gross notional amount of derivatives divided by total assets. $\mathrm{CBI}_{\mathrm{it}}$ is bilaterally netted credit equivalent exposures, $\mathrm{CPO}_{\mathrm{it}}$ is the credit equivalent exposures measuring potential future exposure to market prices volatility, $\mathrm{CTO}_{\mathrm{it}}$ is the risk exposure to assets on total credit exposure, and $\mathrm{CCA}_{\mathrm{it}}$ is the total credit exposure to total assets. Each of $\mathrm{CBI}_{\mathrm{it}}$, $\mathrm{CPO}_{\mathrm{it}}, \mathrm{CTO}_{\mathrm{it}}$ and $\mathrm{CCA}_{\mathrm{it}}$ is normalized by total assets. SIZE $\mathrm{it}_{\mathrm{it}}$ is the asset size and $\mathrm{LEV}_{\mathrm{it}}$ is the debt level, while INF $\mathrm{I}_{\mathrm{t}}, \mathrm{GDP}_{\mathrm{t}}$ and $\mathrm{UN}_{\mathrm{t}}$ are inflation rate, the growth rate of GDP per capita, and unemployment rate, respectively.

of a firm and accordingly provided a positive effect on enterprise value by improving profitability. However, after the financial crisis, the trading volume in OTC derivatives was only marginally significant. Rather, the trading volume in exchange derivatives appears to become significant. This implies that the effects of derivatives trading may vary according to the level of the market risk of the derivatives.
Since the financial crisis, many countries have intensified regulations on large financial institutions due to the concerns for the risk of derivatives. In doing so, the inherent purpose of derivatives trading, which is risk transfer and effective funding, was a little bit ignored. The focus was given in reducing the risk of OTC derivatives.

We have conducted a research on the effects on finan- 
Table 4. Multicollinearity analysis.

\begin{tabular}{|c|c|c|c|}
\hline \multicolumn{2}{|c|}{ (A) Banks and Trust Companies } & \multicolumn{2}{|c|}{ (B) Banks and Financial Holding Companies } \\
\hline $\begin{array}{l}\text { Before the Crisis } \\
\text { (2001Q4-2007Q2) }\end{array}$ & $\begin{array}{c}\text { After the Crisis } \\
\text { (2007Q3-2011Q3) }\end{array}$ & $\begin{array}{l}\text { Before the Crisis } \\
\text { (2001Q4-2007Q2) }\end{array}$ & $\begin{array}{c}\text { After the Crisis } \\
\text { (2007Q3-2011Q3) }\end{array}$ \\
\hline $\operatorname{DEX}_{\mathrm{it}}(5.15)$ & $\operatorname{DEX}_{\mathrm{it}}(8.14)$ & & \\
\hline DOTC $_{\text {it }}(6.74)$ & DOTC $_{\text {it }}(1.52)$ & & \\
\hline $\mathrm{CBI}_{\mathrm{it}}(3947.23)$ & $\mathrm{CBI}_{\mathrm{it}}(1687.09)$ & $\operatorname{DEX}_{\text {it }}(7.83)$ & $\operatorname{DEX}_{\mathrm{it}}(5.23)$ \\
\hline $\mathrm{CPO}_{\text {it }}(1522.59)$ & $\mathrm{CPO}_{\text {it }}(967.24)$ & DOTC $_{\text {it }}(4.19)$ & DOTC $_{\text {it }}(6.78)$ \\
\hline $\mathrm{CTO}_{\text {it }}(3905.11)$ & $\mathrm{CTO}_{\text {it }}(315.30)$ & $\operatorname{SIZE}_{\text {it }}(7.65)$ & $\operatorname{SIZE}_{\mathrm{it}}(2.3)$ \\
\hline $\mathrm{CCA}_{\mathrm{it}}(9.7)$ & $\mathrm{CCA}_{\mathrm{it}}(17.82)$ & $\operatorname{LEV}_{\text {it }}(14.09)$ & $\operatorname{LEV}_{\text {it }}(12.35)$ \\
\hline $\operatorname{SIZE}_{\text {it }}(3.2)$ & $\operatorname{SIZE}_{\text {it }}(6.50)$ & $\operatorname{INF}_{t}(1.89)$ & $\operatorname{INF}_{t}(2.85)$ \\
\hline $\operatorname{LEV}_{\text {it }}(4.0)$ & $\operatorname{LEV}_{\text {it }}(17.39)$ & $\mathrm{GDP}_{\mathrm{t}}(1.37)$ & $\mathrm{GDP}_{\mathrm{t}}(3.62)$ \\
\hline $\mathrm{INF}_{\mathrm{t}}(1.9)$ & $\mathrm{INF}_{\mathrm{t}}(1.9)$ & $\mathrm{UN}_{\mathrm{t}}(1.64)$ & $\mathrm{UN}_{\mathrm{t}}(1.08)$ \\
\hline $\operatorname{GDP}_{t}(1.6)$ & $\operatorname{GDP}_{t}(1.6)$ & & \\
\hline $\mathrm{UN}_{\mathrm{t}}(1.7)$ & $\mathrm{UN}_{\mathrm{t}}(1.7)$ & & \\
\hline
\end{tabular}

Note: $\mathrm{ROA}_{\mathrm{it}}$ is the net profit divided by total assets of institution $\mathrm{i}$ at period t. $\mathrm{DEX}_{\mathrm{it}}$ and $\mathrm{DOTC}_{\mathrm{it}}$ are trading volumes of exchange derivatives and OTC derivatives, respectively, measured by gross notional amount of derivatives divided by total assets. $\mathrm{CBI}_{\mathrm{it}}$ is bilaterally netted cred $\mathrm{i}_{\mathrm{it}}$ equivalent exposures, $\mathrm{CPO}_{\mathrm{it}}$ is the credit equivalent exposures measuring potential future exposure to market prices volatility, $\mathrm{CTO}_{\mathrm{it}}$ is the risk exposure to assets on total credit exposure, and $\mathrm{CCA}_{\text {it }}$ is the total credit exposure to total assets. Each of $\mathrm{CBI}_{\mathrm{it}}, \mathrm{CPO}_{\mathrm{it}}, \mathrm{CTO}_{\mathrm{it}}$ and $\mathrm{CCA}_{\mathrm{it}}$ is normalized by total assets. SIZE debt level, while $\mathrm{INF}_{\mathrm{t}}, \mathrm{GDP}_{\mathrm{t}}$ and $\mathrm{UN}_{\mathrm{t}}$ are inflation rate, the growth rate of GDP per capita, and unemployment rate, respectively.

Table 5. Panel results of the model. (a) Banks and trust companies; (b) Banks and financial holding companies.

(a)

\begin{tabular}{ccccc}
\hline & \multicolumn{2}{c}{ Fixed Effects } & \multicolumn{2}{c}{ Random Effects } \\
\hline & Before the Crisis & After the Crisis & Before the Crisis & After the Crisis \\
& $(2001 \mathrm{Q} 4-2007 \mathrm{Q} 2)$ & $(2007 \mathrm{Q}-2011 \mathrm{Q} 3)$ & $(2001 \mathrm{Q} 4-2007 \mathrm{Q} 2)$ & $(2007 \mathrm{Q}-2011 \mathrm{Q} 3)$ \\
$\mathrm{DEX}_{\text {it }}$ & $0.01(0.67)$ & $0.16(1.02)$ & $-0.01(-0.12)$ & $0.24^{* *}(2.27)$ \\
$\mathrm{DOTC}_{\text {it }}$ & $0.22^{*}(2.17)$ & $0.76(1.83)$ & $1.37^{* *}(3.49)$ & $0.43(0.04)$ \\
$\mathrm{CCA}_{\text {it }}$ & $0.18(0.02)$ & $0.46(0.52)$ & $0.06(0.18)$ & $0.90(0.06)$ \\
$\mathrm{SIZE}_{\text {it }}$ & $-0.00(-0.03)$ & $-0.01(-0.09)$ & $0.09(1.00)$ & $0.04^{* * *}(2.45)$ \\
$\mathrm{LEV}_{\text {it }}$ & $0.00(0.02)$ & $0.10(0.92)$ & $0.71(0.29)$ & $0.00(0.65)$ \\
$\mathrm{INF}_{\mathrm{t}}$ & $0.30(0.19)$ & $0.86(0.98)$ & $0.05(0.18)$ & $0.22(1.62)$ \\
$\mathrm{GDP}_{\mathrm{t}}$ & $0.03(1.00)$ & $0.24(1.03)$ & $-0.24(-0.27)$ & $-0.92(-1.22)$ \\
$\mathrm{UN}_{\mathrm{t}}$ & $0.14(0.96)$ & $-0.98(-0.17)$ & $0.40(0.94)$ & $-3.32(-1.07)$ \\
Modified R2 & 0.34 & 0.12 & 0.32 & 0.11 \\
$\mathrm{~N}$ & 230 & 170 & 230 & 170 \\
\hline
\end{tabular}

(b)

\begin{tabular}{ccccc}
\hline & \multicolumn{2}{c}{ Fixed Effects } & \multicolumn{2}{c}{ Random Effects } \\
\hline & $\begin{array}{c}\text { Before the Crisis } \\
(2001 \mathrm{Q}-2007 \mathrm{Q} 2)\end{array}$ & $\begin{array}{c}\text { After the Crisis } \\
(2007 \mathrm{Q}-2011 \mathrm{Q} 3)\end{array}$ & $\begin{array}{c}\text { Before the Crisis } \\
(2001 \mathrm{Q} 4-2007 \mathrm{Q} 2)\end{array}$ & $\begin{array}{c}\text { After the Crisis } \\
(2007 \mathrm{Q} 3-2011 \mathrm{Q} 3)\end{array}$ \\
$\mathrm{DEX}_{\mathrm{it}}$ & $0.03(0.61)$ & $0.17^{*}(1.99)$ & $-0.02(-0.08)$ & $1.40(0.00)$ \\
DOTC $_{\mathrm{it}}$ & $0.08^{*}(2.09)$ & $-0.21(-0.81)$ & $0.30^{* * *}(7.57)$ & $0.29(0.94)$ \\
$\mathrm{SIZE}_{\mathrm{it}}$ & $0.04^{* * *}(4.12)$ & $-0.02^{* *}(-2.21)$ & $0.02(1.02)$ & $-1.92^{* * *}(-2.86)$ \\
$\mathrm{INF}_{\mathrm{t}}$ & $0.03^{* *}(2.38)$ & $-0.62(-4.29)$ & $-0.22(-0.02)$ & $-0.94(-1.00)$ \\
$\mathrm{GDP}_{\mathrm{t}}$ & $-0.66^{* * *}(-3.61)$ & $7.12(0.23)$ & $0.48(0.118)$ & $3.30(1.02)$ \\
$\mathrm{UN}_{\mathrm{t}}$ & $0.73^{* * *}(8.02)$ & $0.62^{* *}(2.17)$ & $0.70^{* * *}(2.39)$ & $1.03(0.01)$ \\
Modified R2 & 0.27 & 0.40 & 0.22 & 0.37 \\
$\mathrm{~N}$ & 276 & 204 & 276 & 204 \\
\hline
\end{tabular}

Note: Dependent Variable: $\mathrm{ROA}_{\mathrm{it} .}{ }^{* * *}$ : Significant at $1 \%{ }^{* *}:$ At $5 \% .^{*}:$ At $10 \%$. $\mathrm{ROA}_{\mathrm{it}}$ is the net profit divided by total assets of institution $\mathrm{i}$ at period t. DEX and DOTC $\mathrm{it}_{\mathrm{it}}$ are trading volumes of exchange derivatives and OTC derivatives, respectively, measured by gross notional amount of derivatives divided by total assets. $\mathrm{CBI}_{\mathrm{it}}$ is bilaterally netted credit equivalent exposures, $\mathrm{CPO}_{\mathrm{it}}$ is the credit equivalent exposures measuring potential future exposure to market prices volatility, $\mathrm{CTO}_{\mathrm{it}}$ is the risk exposure to assets on total credit exposure, and $\mathrm{CCA}_{\mathrm{it}}$ is the total credit exposure to total assets. Each of $\mathrm{CBI}_{\mathrm{it}}$, $\mathrm{CPO}_{\mathrm{it}}, \mathrm{CTO}_{\mathrm{it}}$ and $\mathrm{CCA}_{\mathrm{it}}$ is normalized by total assets. SIZE $\mathrm{it}_{\mathrm{it}}$ is the asset size and $\mathrm{LEV}_{\mathrm{it}}$ is the debt level, while $\mathrm{INF}_{\mathrm{t}}, \mathrm{GDP}_{\mathrm{t}}$ and $\mathrm{UN}_{\mathrm{t}}$ are inflation rate, the growth rate of GDP per capita, and unemployment rate, respectively. 
cial institutions when there is an increase in derivatives trade volume in financial institutions and identify that the kinds of derivatives products that affect positively or negatively the enterprise value of financial institutions may vary according to each period of the economy. In consideration of the findings, more appropriate alternatives should be provided to the regulations of derivatives products, inspection of the derivatives market, and trading methods of financial institutions.

\section{Acknowledgements}

This research is financially supported by 2013 Research Fund of Hankuk University of Foreign Studies.

\section{REFERENCES}

[1] D. Ryu, J. Baek, J. Yang and J. Chae, "Derivatives Trading Volume and Abnormal Return," Unpublished Manuscript, 2011.

[2] T. Kwon, R. Park and U. Chang, "Derivatives Use, Firm Value, Risk and Determinants: Evidence of Korean Firms,"
Korean Journal of Futures and Options, Vol. 19, No. 4, 2011, pp. 335-362.

[3] A. Jalivand, "Why Firms Use Derivatives: Evidence From Canada," Canadian Journal of Administrative Sciences, Vol. 16, No. 3, 1999, pp. 213-225. doi:10.1111/j.1936-4490.1999.tb00197.x

[4] T. Brunzell, M. Hansson and E. Liljeblom, "The Use of Derivatives in Nordic Firms," European Journal of Finance, Vol. 17, No. 5-6, 2011, pp. 355-376. doi: 10.1080/1351847X.2010.543836

[5] A. S. Ahmed, E. Kilic and G. J. Lobo, "Effects of SFAS 133 on the Risk Relevance of Accounting Measures of Banks' Derivative Exposures," Accounting Review, Vol. 86, No. 3, 2011, pp. 769-804. doi: $10.2308 /$ accr.00000033

[6] X. Fu and S. A. Heffernan, "The Effects of Reform on China's Bank Structure and Performance," Journal of Banking and Finance, Vol. 33, No. 1, 1999, pp. 39-52. doi:10.1016/j.jbankfin.2006.11.023 